\title{
Biomarkers for Optimization and Personalization of Anti-TNFs in Pediatric Inflammatory Bowel Disease
}

\author{
Sara Salvador-Martín ${ }^{1}$, Alejandra Melgarejo-Ortuño ${ }^{1}$ (D) and Luis A. López-Fernández ${ }^{1,2, *(D)}$ \\ 1 Servicio de Farmacia, Instituto de Investigación Sanitaria Gregorio Marañón, \\ Hospital General Universitario Gregorio Marañón, 28007 Madrid, Spain; \\ sara.salvador@iisgm.com (S.S.-M.); Alejandra.melgarejo@salud.madrid.org (A.M.-O.) \\ 2 Spanish Clinical Research Network (SCReN), 28040 Madrid, Spain \\ * Correspondence: Luis.lopez@iisgm.com
}

Citation: Salvador-Martín, S.

Melgarejo-Ortuño, A.; López-

Fernández, L.A. Biomarkers for Optimization and Personalization of Anti-TNFs in Pediatric Inflammatory Bowel Disease. Pharmaceutics 2021, 13 , 1786. https://doi.org/10.3390/ pharmaceutics 13111786

Academic Editor: José B. Fariña

Received: 10 September 2021

Accepted: 15 October 2021

Published: 26 October 2021

Publisher's Note: MDPI stays neutral with regard to jurisdictional claims in published maps and institutional affiliations.

Copyright: (c) 2021 by the authors. Licensee MDPI, Basel, Switzerland. This article is an open access article distributed under the terms and conditions of the Creative Commons Attribution (CC BY) license (https:/ / creativecommons.org/licenses/by/ $4.0 /)$.

\begin{abstract}
The use of biological drugs has improved outcomes in pediatric inflammatory bowel disease (IBD). Prediction of the response to biological drugs would be extremely useful in IBD, and even more so in children, who are still growing physically and psychologically. Specific clinical, biochemical, and genetic parameters are considered predictive of response to biological drugs, although few studies have been carried out in children with IBD. In this review, we present current evidence on biological treatments used in pediatric IBD and the available biomarkers of response. We examine demographics, clinical characteristics, biomarkers (genetic, genomic, and cellular), and microbiota.
\end{abstract}

Keywords: biomarkers; pharmacogenomics; personalized medicine; inflammatory bowel disease; infliximab; adalimumab; Crohn's disease; ulcerative colitis

\section{Introduction}

Inflammatory bowel disease (IBD) is a chronic immune-mediated condition that affects the gastrointestinal tract. Almost $25 \%$ of cases are diagnosed before the age of 18 years [1], $20 \%$ before the age of 10 years [2], and $5 \%$ before the age of 6 years [3]. The incidence of the disease in children is increasing [4]. However, most clinical trials in this disease have been carried out in adults, and the results have been extrapolated with minimal changes to determine treatment in children. Pediatric IBD (pIBD) is characterized by various factors, including a more severe phenotype than adult disease [5,6]. Since IBD is a chronic autoimmune disease, patients diagnosed during childhood live longer with the illness and consequently need treatment for longer.

Biological drugs and, more specifically, anti-TNF drugs such as infliximab and adalimumab have proven efficient for treatment of IBD in adults and in children [7]. However, the use of biological drugs differs between children and adults with IBD [8]. For instance, the time between diagnosis and initiation of biological treatment is shorter in children than in adults $[9,10]$. In addition, not all the biological drugs approved for adult IBD are approved for children. Therefore, treatment with biological drugs should be personalized as much as possible in pIBD in order to avoid early non-response and maximize duration of response in children.

There is an urgent unmet need for predicting response prior to treatment initiation to reduce healthcare costs and avoid unnecessary treatment, allowing a more rational use of resources. While identification of biomarkers for response to biologics in IBD has been a priority in the last 15 years, results have only been partially positive. Unfortunately, most biomarkers have been identified in adults or in populations combining adults and children [11]. Very few studies have been performed exclusively in children with IBD, although the results do point to common biomarkers for both populations and to others 
that are specific for children. Since susceptibility to IBD differs between the two populations $[12,13]$, there may also be differences in their response to the biological drugs used to treat the disease. Separate searches were performed for each part of the review and once the manuscripts were analyzed, they led to other articles not detected in the searches. Some manuscripts mentioned in the review were included because of a thorough and regular reading of manuscripts over the years on this topic by the authors.

In this review, we summarize clinical, biochemical, genetic, genomic, and cellular biomarkers of response to biological drugs in pIBD.

\section{Pediatric Inflammatory Bowel Disease. Differences with Adults}

\subsection{Clinical Differences}

The natural history of pIBD is characterized by a more severe phenotype than in adults. Regarding extension, intestinal involvement is more relevant in childhood, with more rapid and aggressive disease progression [14-16]. A study comparing IBD patients (21,200 adults and 846 children) confirmed this evidence and demonstrated that childhoodonset IBD was associated with an higher risk of immunomodulator use [17]. In children, the most common symptoms include diarrhea with or without blood, abdominal pain, and malnutrition [18].

Approximately $50 \%$ of patients experience extraintestinal disorders, which are usually the initial manifestations of the disease [19]. In children, these are associated with more severe disease course [20] and include weight loss, growth failure, late pubertal development, and psychosocial problems [21,22], all of which are particularly relevant in this population. Extraintestinal manifestations are very frequent in pediatric Crohn's disease (pCD), affecting $10-30 \%$ of cases $[21,23,24]$.

Differences in CD and ulcerative colitis (UC) between adults and children have led to the modification of the adult Montreal classification, which has been adapted to the pediatric population, and to the creation of a new classification, the Paris classification, which reflects changes that may occur during childhood and also allows for growth abnormalities, which, as previously mentioned, are very relevant in this population [2,25].

In summary, developing pediatric IBD, an incurable inflammatory intestinal disease that influences growth and puberty in patients at a vulnerable psychosocial age is even more challenging than when it is diagnosed in adults.

\subsection{Treatment of Pediatric IBD}

The goal of the treatment of pediatric IBD is to induce and maintain clinical remission, achieve normal growth, provide optimal quality of life, promote psychological health, and reduce toxicity as much as possible. Additionally, the gold standard of optimal therapy is endoscopic mucosal healing, which makes it possible to modify the natural history of the disease and prevent complications of progressive bowel destruction. In observational adult studies, younger age at onset is repeatedly considered high-risk for poor prognosis, thus underlining the need for a highly effective treatment approach in children [26].

Treatment is selected based on the location, type of disease, severity of symptoms, and the goal of therapy (induction therapy or maintenance of remission). The pharmacological arsenal for pIBD treatment includes anti-inflammatory drugs such as aminosalicylates, corticosteroids, and immunomodulatory drugs (for example, thiopurines and methotrexate), which are used as maintenance therapy, and biologic drugs, which are used for induction and maintenance of remission. The doses and treatment guidelines for biologic drugs are very similar to those of adults, even though the metabolism and immune system of children may differ from those of adults [27-29].

The introduction of monoclonal antibodies against tumor necrosis factor (anti-TNF) revolutionized the treatment of IBD. Infliximab and adalimumab are the two anti-TNF agents approved by the United States Food and Drug Administration (FDA) and the European Medicines Agency for use in children, although adalimumab is not approved in perianal pCD [30]. Infliximab is administered as an intravenous infusion and adalimumab 
is administered subcutaneously for induction and maintenance therapy. Studies have shown that early use of anti-TNF drugs in children with CD is associated with increased rates of remission and mucosal healing, as well as with modest improvement in linear growth [15,30-32].

Recently, the European Crohn's and Colitis Organization (ECCO) and the Paediatric IBD Porto group of the European Society of Paediatric Gastroenterology, Hepatology, and Nutrition (ESPGHAN) updated their recommendations for the medical management of pCD [33]. According to their guidelines, patients with perianal disease, penetrating type, or severe growth retardation should be considered for up-front anti-TNF treatment in combination with an immunomodulator.

Advances in the understanding of the etiology and pathogenesis of IBD in recent years have led to the development of new drugs based on inhibition of immune cells [34] or inhibition of cytokine signaling [35-37]. New categories of biologic drugs that have been shown to be effective and safe in adults are the new horizon for IBD treatment in children [30]. Some biological drugs that are currently approved in adults, such as vedolizumab or ustekinumab, are used off-label in children when treatment with infliximab or adalimumab fails [38].

Despite advances in medical treatment, surgery may still be warranted in refractory pIBD [26]. In pCD, the median time to first surgery is longer than in patients who debut in adulthood, although the need for surgery in pUC is earlier than in adults. Consequently, the risk of surgical resection before the age of 30 years is higher in children than in adults [39].

\section{Clinical and Biochemical Biomarkers of Response to Anti-TNFs in pIBD}

Anti-TNF $\alpha$ drugs have proven to be effective and safe for pIBD [14], although approximately one third of patients who initially respond to anti-TNF therapy lose that response over time [40,41]; and while various clinical and biochemical characteristics predict response to anti-TNF therapy, these are mainly based on studies in adult populations [42] The characteristics include disease-related factors (such as disease phenotype, behavior, location, and severity), biochemical parameters (such as C-reactive protein, fecal calprotectin, and albumin levels) and drug-related characteristics (such as pharmacokinetic, pharmacodynamic, and immunogenic factors) [43-47]. The ECCO-ESPGHAN guideline update on management of $\mathrm{CD}$ in children recommends monitoring of fecal calprotectin or small bowel imaging as the best markers of treatment response [33].

The PANTS study is one of the few studies to evaluate the response to anti-TNFs in a population including children and adolescents over 6 years of age, although to date, no subanalysis of pediatric patients has been performed. Obesity, smoking, low albumin concentrations, higher baseline markers of disease activity, and development of immunogenicity were associated with low drug concentrations during induction, resulting in non-remission at week 54 after initiation of anti-TNF treatment [48].

The level of anti-TNF agent immediately before the following administration, known as the trough level, is increasingly used as a non-invasive biomarker. It is well known that serum levels of infliximab and adalimumab correlate with treatment response in patients with IBD [49,50] and pIBD [51-54]. Furthermore, these levels are associated with histological and endoscopic disease remission in both populations [55-58].

The therapeutic range of these drugs varies considerably, especially in pIBD. Most guidelines indicate that to achieve clinical remission of IBD, infliximab and adalimumab concentrations in the range of 3-7 and 5-12 $\mu \mathrm{g} / \mathrm{mL}$, respectively, are considered adequate [43,59-62]. The therapeutic ranges of both anti-TNF drugs may vary depending on the disease phenotype or on the treatment goals $[48,58,63]$. Further studies are needed to define optimal levels.

Anti-TNF drugs are antibodies against TNF that can induce the immune response and generate anti-drug antibodies (ADAs). ADAs bind to the anti-TNF drug, thus reducing free functional drug levels, neutralizing the therapeutic effect, and resulting in a loss of 
response [64]. ADA levels inversely correlate with drug levels and treatment response in adults [45,65], as well as in children [66-69].

For this reason, therapeutic drug monitoring (TDM) has been proposed as a means of optimizing biological therapies in both adults [70-73] and children [52,74-76] with IBD. This approach appears to be more advantageous in pediatric patients, since fluctuations in pharmacokinetic variables tend to be more pronounced in children than in adults, possibly owing to physiological differences, such as volume of distribution, and immaturity of enzyme systems and of clearance mechanisms [52]. In fact, Jongsma MME et al. reported that, over one year of treatment with infliximab, patients under 10 years of age require a more intensive treatment regimen than older patients and that these patients are more likely to develop antibodies to infliximab [77].

Data on the optimal timing of TDM are conflicting, since some professionals use reactive monitoring, i.e., measuring drug levels in the case of loss of response, whereas others use proactive monitoring, i.e., measuring them at preset time points [78]. Proactive monitoring has been shown to achieve clinical improvement and endoscopic remission in IBD patients treated with anti-TNFs [79-81], as well as in children [82,83]. However, this issue is quite controversial and, in fact, the recommendations form the ECCO for adults are indecisive [33].

The current recommendation in pIBD is to measure drug levels and ADA titers after the induction period, even though studies in this population are insufficient and data are conflicting $[30,54,84]$. The use of TDM in pIBD is increasing in clinical practice, and efficacy similar to that of adults has been demonstrated in children, with loss of response to anti-TNF therapy [51].

Considering the high cost and potentially severe side effects of anti-TNF biologics, the identification of underlying factors involved in the individual responses is sorely needed. The usefulness of TDM is therefore limited, as monitoring helps physicians to modify the existing treatment by adjusting the dose of the biological drug and/or the frequency of administration. However, to choose the best biological drug and the best starting dose, other types of biomarkers are needed. Moreover, these new biomarkers should be inexpensive and easy to implement in clinical routine, which is not always simple.

\section{Genomic Biomarkers of Response to Anti-TNFs in pIBD}

Pharmacogenomics may play an important role in predicting response, mainly before initiation of anti-TNF treatment in pIBD. Genetic variants and gene expression could be useful markers for predicting response to biological drugs in children with IBD. Since pediatric patients will have to live longer with the disease and will therefore need treatment for longer, identification of pharmacogenomic biomarkers with the aim of personalizing treatment is especially important in this population.

\subsection{Genetic Variants}

The genetics of pIBD differs from that of adult IBD, thus highlighting the relevance of finding specific biomarkers for children [85]. Several single-nucleotide polymorphisms (SNPs) have been associated with the response to anti-TNF drugs in adult patients with CD, $\mathrm{UC}$, or IBD. The most relevant SNPs are located at various sites: in genes involved in the NF$\mathrm{kB}$ signaling pathway activated through TLR2, TLR4, TLR5, TLR9, LY96, CD14, MAP3K14, NFKBIA, and NFKB1; in genes of the TNF signaling pathway activated through TNF, TNFRSF1A, TNFRSF1B, and TNFAIP3 and other cytokines and their receptors regulated by this pathway, such as IL1B, IL1RN, IL6, IL10, IL17A, and IFN; in other genes involved in the regulation of inflammation, for instance, IL4R, IL6R, IL23R, TGFB1, PTPN22, PPARG, and NLRP3; and in genes involved in autophagy and apoptosis, such as ATG16L1, ATG12, and ATG5 and FASLG and FCGR3A $[9,44,86-96]$.

Of note, information on these biomarkers of response to infliximab and adalimumab in pIBD is lacking. Few studies have included children [97], and even fewer have focused only on children [98-101]. The two main strategies followed are selection of genome-wide 
association studies (GWAS) $[97,98]$ and selection of SNPs [10,101]. Another approach has been to identify the genetic variants associated with parameters that correlate with a higher probability of response, such as biological drug trough level $[100,101]$.

Dubinsky et al. aimed to find SNPs associated with response to anti-TNF drugs in 94 children with IBD by GWAS in order to develop a predictive model for primary antiTNF $\alpha$ non-response [98]. The authors found 65 SNPs associated with primary response to infliximab in pIBD with a $p$ value $<0.0001$ (Table 1). They then tested for predictive models of non-response to infliximab. The best predictive model included diagnosis, pANCA, and the following SNPs: rs2836878 (BRWD1), rs975664 (TACR1), rs4855535 (FAM19A4), and rs6100556 (PHACTR3) [98]. The SNP rs2836878 was one of the susceptibility loci for pIBD and had not previously been reported in adults with IBD [102]. This does not indicate that it is not associated with adult IBD, but rather suggests that there may be differences between the two populations, thus highlighting the importance of separating them when studying pharmacogenetic markers. The study by Dubinsky et al. is the largest to try to identify genetic variants associated with response to biological drugs in children with IBD.

Table 1. Genetic variants associated with response or factors related to response to biological drugs in pediatric inflammatory bowel disease.

\begin{tabular}{|c|c|c|c|c|c|}
\hline Gen & RS ID & Effect & Treatment & Patient (Age) & Reference \\
\hline ATG16L1 & rs2241880 & PNR & IFX & $\mathrm{CD}+\mathrm{UC}(<21)$ & [98] \\
\hline$I R F-A S 1$ & rs2188962 & PNR & IFX & $\mathrm{CD}+\mathrm{UC}(<21)$ & [98] \\
\hline CDKAL1 & rs6908425 & PNR & IFX & $\mathrm{CD}+\mathrm{UC}(<21)$ & [98] \\
\hline None & rs762421 & PNR & IFX & $\mathrm{CD}+\mathrm{UC}(<21)$ & [98] \\
\hline None & rs2395185 & PNR & IFX & $\mathrm{CD}+\mathrm{UC}(<21)$ & [98] \\
\hline$B R W D 1$ & rs2836878 & PNR & IFX & $\mathrm{CD}+\mathrm{UC}(<21)$ & [98] \\
\hline TACR1 & rs975664 & PNR & IFX & $\mathrm{CD}+\mathrm{UC}(<21)$ & [98] \\
\hline TAFA4 & rs4855535 & PNR & IFX & $\mathrm{CD}+\mathrm{UC}(<21)$ & [98] \\
\hline None & rs4796606 & PNR & IFX & $\mathrm{CD}+\mathrm{UC}(<21)$ & [98] \\
\hline PHACTR3 & rs6100556 & PNR & IFX & $\mathrm{CD}+\mathrm{UC}(<21)$ & [98] \\
\hline CNBD1 & rs2943177 & PNR & IFX & $\mathrm{CD}+\mathrm{UC}(<21)$ & [98] \\
\hline COL22A1 & rs11991611 & PNR & IFX & $\mathrm{CD}+\mathrm{UC}(<21)$ & [98] \\
\hline DOCK1 & rs3740543 & PNR & IFX & $\mathrm{CD}+\mathrm{UC}(<21)$ & [98] \\
\hline LRRC7 & rs7521532 & PNR & IFX & $\mathrm{CD}+\mathrm{UC}(<21)$ & [98] \\
\hline CLSTN2 & rs4605505 & PNR & IFX & $\mathrm{CD}+\mathrm{UC}(<21)$ & [98] \\
\hline TNFRSF21 & rs2103867 & PNR & IFX & $\mathrm{CD}+\mathrm{UC}(<21)$ & [98] \\
\hline PHACTR1 & rs10485363 & PNR & IFX & $\mathrm{CD}+\mathrm{UC}(<21)$ & [98] \\
\hline HAPLN2 & rs3795727 & PNR & IFX & $\mathrm{CD}+\mathrm{UC}(<21)$ & [98] \\
\hline PHACTR1 & rs6906890 & PNR & IFX & $\mathrm{CD}+\mathrm{UC}(<21)$ & [98] \\
\hline NLRP13 & rs302827 & PNR & IFX & $\mathrm{CD}+\mathrm{UC}(<21)$ & [98] \\
\hline ETV6 & rs2723829 & PNR & IFX & $\mathrm{CD}+\mathrm{UC}(<21)$ & [98] \\
\hline$L R P 1 B$ & rs1372256 & PNR & IFX & $\mathrm{CD}+\mathrm{UC}(<21)$ & [98] \\
\hline DCHS2 & rs13138970 & PNR & IFX & $\mathrm{CD}+\mathrm{UC}(<21)$ & [98] \\
\hline KIAA1755 & rs1205434 & PNR & IFX & $\mathrm{CD}+\mathrm{UC}(<21)$ & [98] \\
\hline TACR1 & rs7588326 & PNR & IFX & $\mathrm{CD}+\mathrm{UC}(<21)$ & [98] \\
\hline TACR1 & rs3771823 & PNR & IFX & $\mathrm{CD}+\mathrm{UC}(<21)$ & [98] \\
\hline ATXN1 & rs12527937 & PNR & IFX & $\mathrm{CD}+\mathrm{UC}(<21)$ & [98] \\
\hline KCNQ5 & rs3757105 & PNR & IFX & $\mathrm{CD}+\mathrm{UC}(<21)$ & [98] \\
\hline CNTN1 & rs278917 & PNR & IFX & $\mathrm{CD}+\mathrm{UC}(<21)$ & [98] \\
\hline HAPLN2 & rs12567958 & PNR & IFX & $\mathrm{CD}+\mathrm{UC}(<21)$ & [98] \\
\hline CNBD1 & rs1880473 & PNR & IFX & $\mathrm{CD}+\mathrm{UC}(<21)$ & [98] \\
\hline LINC00290 & rs7689941 & PNR & IFX & $\mathrm{CD}+\mathrm{UC}(<21)$ & [98] \\
\hline GPC3 & rs1264379 & PNR & IFX & $\mathrm{CD}+\mathrm{UC}(<21)$ & [98] \\
\hline TPST2 & rs3088103 & PNR & IFX & $\mathrm{CD}+\mathrm{UC}(<21)$ & [98] \\
\hline TRERF1 & rs 4711716 & PNR & IFX & $\mathrm{CD}+\mathrm{UC}(<21)$ & [98] \\
\hline$M G A M$ & rs10464448 & PNR & IFX & $\mathrm{CD}+\mathrm{UC}(<21)$ & [98] \\
\hline EEPD1 & rs2540678 & PNR & IFX & $\mathrm{CD}+\mathrm{UC}(<21)$ & [98] \\
\hline LINC00290 & rs7659755 & PNR & IFX & $\mathrm{CD}+\mathrm{UC}(<21)$ & [98] \\
\hline
\end{tabular}


Table 1. Cont.

\begin{tabular}{|c|c|c|c|c|c|}
\hline Gen & RS ID & Effect & Treatment & Patient (Age) & Reference \\
\hline None & rs770389 & PNR & IFX & $\mathrm{CD}+\mathrm{UC}(<21)$ & [98] \\
\hline CNTN1 & rs7309734 & PNR & IFX & $\mathrm{CD}+\mathrm{UC}(<21)$ & [98] \\
\hline CPA6 & rs10808755 & PNR & IFX & $\mathrm{CD}+\mathrm{UC}(<21)$ & [98] \\
\hline RBM26 & rs1155848 & PNR & IFX & $\mathrm{CD}+\mathrm{UC}(<21)$ & [98] \\
\hline None & rs1592749 & PNR & IFX & $\mathrm{CD}+\mathrm{UC}(<21)$ & [98] \\
\hline None & rs765132 & PNR & IFX & $\mathrm{CD}+\mathrm{UC}(<21)$ & [98] \\
\hline None & rs4707930 & PNR & IFX & $\mathrm{CD}+\mathrm{UC}(<21)$ & [98] \\
\hline None & rs7905482 & PNR & IFX & $\mathrm{CD}+\mathrm{UC}(<21)$ & [98] \\
\hline None & rs7059861 & PNR & IFX & $\mathrm{CD}+\mathrm{UC}(<21)$ & [98] \\
\hline None & rs5975453 & PNR & IFX & $\mathrm{CD}+\mathrm{UC}(<21)$ & [98] \\
\hline None & rs4077511 & PNR & IFX & $\mathrm{CD}+\mathrm{UC}(<21)$ & [98] \\
\hline None & rs2825673 & PNR & IFX & $\mathrm{CD}+\mathrm{UC}(<21)$ & [98] \\
\hline None & rs7003556 & PNR & IFX & $\mathrm{CD}+\mathrm{UC}(<21)$ & [98] \\
\hline None & rs1243519 & PNR & IFX & $\mathrm{CD}+\mathrm{UC}(<21)$ & [98] \\
\hline None & rs2044111 & PNR & IFX & $\mathrm{CD}+\mathrm{UC}(<21)$ & [98] \\
\hline$D G K B$ & rs17168564 & PNR & IFX & $\mathrm{CD}+\mathrm{UC}(<21)$ & [98] \\
\hline LOC105379171 & rs7726515 & PNR & IFX & $\mathrm{CD}+\mathrm{UC}(<21)$ & [98] \\
\hline TSPAN18 & rs835780 & PNR & IFX & $\mathrm{CD}+\mathrm{UC}(<21)$ & [98] \\
\hline TSPAN18 & rs835791 & PNR & IFX & $\mathrm{CD}+\mathrm{UC}(<21)$ & [98] \\
\hline TSPAN18 & rs7124825 & PNR & IFX & $\mathrm{CD}+\mathrm{UC}(<21)$ & [98] \\
\hline None & rs9556658 & PNR & IFX & $\mathrm{CD}+\mathrm{UC}(<21)$ & [98] \\
\hline None & rs1555901 & PNR & IFX & $\mathrm{CD}+\mathrm{UC}(<21)$ & [98] \\
\hline None & rs4465121 & PNR & IFX & $\mathrm{CD}+\mathrm{UC}(<21)$ & [98] \\
\hline None & rs10269232 & PNR & IFX & $\mathrm{CD}+\mathrm{UC}(<21)$ & [98] \\
\hline DGS2-AS1 & rs1667216 & PNR & IFX & $\mathrm{CD}+\mathrm{UC}(<21)$ & [98] \\
\hline None & rs9404502 & PNR & IFX & $\mathrm{CD}+\mathrm{UC}(<21)$ & [98] \\
\hline None & rs5977968 & PNR & IFX & $\mathrm{CD}+\mathrm{UC}(<21)$ & [98] \\
\hline None & rs12937472 & PNR & IFX & $\mathrm{CD}+\mathrm{UC}(<21)$ & [98] \\
\hline None & rs4301261 & PNR & IFX & $\mathrm{CD}+\mathrm{UC}(<21)$ & [98] \\
\hline None & rs6529954 & PNR & IFX & $\mathrm{CD}+\mathrm{UC}(<21)$ & [98] \\
\hline None & rs12559781 & PNR & IFX & $\mathrm{CD}+\mathrm{UC}(<21)$ & [98] \\
\hline None & rs2825699 & PNR & IFX & $\mathrm{CD}+\mathrm{UC}(<21)$ & [98] \\
\hline$D C D C 2 C$ & rs11903032 & PNR & IFX & $\mathrm{CD}+\mathrm{UC}(<21)$ & [98] \\
\hline TLR4 & rs5030728 & SubT-IFX & IFX & $\mathrm{CD}+\mathrm{UC}(<18)$ & [100] \\
\hline \multirow[t]{2}{*}{ LY96 } & rs11465996 & LTR & IFX, ADL & $\mathrm{UC}(<18)$ & [100] \\
\hline & & SubT-IFX & IFX & CD+UC $(<18)$ & [100] \\
\hline \multirow[t]{2}{*}{ TLR2 } & rs1816702 & SupT-IFX & IFX & $\mathrm{CD}+\mathrm{UC}(<18)$ & [100] \\
\hline & & AB-ADL & ADL & $\mathrm{CD}+\mathrm{UC}(<18)$ & [100] \\
\hline \multirow[t]{2}{*}{ TNFRSF1B } & rs3397 & LTR & IFX, ADL & $\mathrm{CD}(<18)$ & [100] \\
\hline & & SubT-ADL & ADL & CD+UC $(<18)$ & [100] \\
\hline \multirow[t]{3}{*}{ CD14/TMCO6 } & rs2569190 & AB-IFX & IFX & $\mathrm{CD}+\mathrm{UC}(<18)$ & [100] \\
\hline & & AB-ADL & ADL & $\mathrm{CD}+\mathrm{UC}(<18)$ & [100] \\
\hline & & Sup-IFX & IFX & $\mathrm{CD}+\mathrm{UC}(<18)$ & [100] \\
\hline IL10/IL19 & rs1800872 & LTR & IFX, ADL & $\mathrm{CD}(<18)$ & [100] \\
\hline \multirow[t]{2}{*}{ IL17A } & rs2275913 & LTR & IFX, ADL & $\mathrm{CD}(<18)$ & [100] \\
\hline & rs10499563 & LTR & IFX, ADL & $\mathrm{CD}(<18)$ & [100] \\
\hline$H L A-D Q A 1^{*} 05$ & & Higher immunogenicity & & & [97] \\
\hline FCGR3A & rs396991 & $\begin{array}{l}\text { RCR, Higher immunogenicity, } \\
\text { Lower IFX levels }\end{array}$ & IFX & CD+UC (7-18) & [101] \\
\hline
\end{tabular}

PNR, primary non-response; LTR, long-term response; CD, Crohn's disease; UC, ulcerative colitis; IFX, infliximab; ADL, adalimumab; SubT, subtherapeutic trough levels; SupT, supratherapeutic trough levels; AB, absolute trough level; RCR, reduced clinical response at the end of induction, at 22 weeks and at 52 weeks. 
Our group recently applied another strategy to analyze response to anti-TNFs in pIBD. We used Kaplan-Meier curves to analyze 21 SNPs in TLR2, TLR4, TLR9, LY96, CD14, MMP3K14, TNFRSF1A, TNFRSF1B, TNF, TNFAIP3, FASLG, IL10, IL1B, IL6, and IL17A in association with long-term response in pediatric patients diagnosed with CD or UC [10]. Using this approach, we identified the polymorphisms rs1800872 (IL10), rs2275913 (IL17A), rs10499563 (IL6), and rs3397 (TNFRSF1B) as being associated with response to anti-TNF agents in $\mathrm{pCD}$. None of these SNPs was significantly associated with response to infliximab in adults diagnosed with CD, suggesting that they could be differential biomarkers for response to biological drugs in children [9]. In the same study, the SNP rs11465996 in LY96 was associated with response to anti-TNF drugs in pUC. This SNP has not yet been studied in adults with UC.

Another strategy used to identify SNPs related to efficacy of biological drugs in pIBD is the use of parameters associated with a higher probability of response, such as biological drug trough level (see above).

This strategy was first successfully tested in adults with CD treated with infliximab [9]. The same approach was subsequently used to identify genetic polymorphisms associated with serum trough levels of infliximab and adalimumab during maintenance therapy in children diagnosed with IBD (Table 1) [100]. Remarkably, patients with rs1816702 CC (TLR2) had almost double the serum trough levels of patients with the CT or TT genotypes. This difference was not observed in serum trough infliximab levels. These differences between infliximab and adalimumab could facilitate selection between the drugs according to genotype.

Since anti-drug antibodies are associated with failure of biological drugs in IBD, genetic variants associated with the presence of these antibodies could be useful for predicting response to the drugs. Along these lines, Sazonovs A et al. found that patients carrying the HLA-DQA ${ }^{*} 05$ allele more frequently had antibodies against anti-TNF agents in adults and in pediatric patients (aged six years or older) with CD. The finding was associated with a worse response to these treatments [97]. Up to $90 \%$ of CD patients who received infliximab and carried HLA*DQA1*05 had developed anti-infliximab antibodies by week 54 . This is a potential biomarker that should be specifically explored in children.

Consistent with our approach, other authors explored the association of the SNPs rs3936991 (FCGR3A) and rs1800629 (TNF) with response, serum trough levels, and ADA production in IBD patients treated with infliximab [101]. Curci et al. showed that variant C rs396991 was associated with a poorer clinical response at the end of induction and at 22 and at 52 weeks of treatment with infliximab. In addition, patients with this variant had lower infliximab levels and were more likely to produce ADAs than patients with the wild-type genotype [101].

Unfortunately, none of the SNPs that have been associated with response to anti-TNFs in children have been validated in other studies. More studies are needed to explore the usefulness of these biomarkers. More genetic data are necessary to personalize anti-TNF therapy in patients with pIBD according to type of disease and biological drug to be used.

\subsection{Biomarkers of Gene Expression}

Specific gene expression profiles in the inflamed tissues of adult patients with CD and UC have been associated with response to anti-TNF drugs. The genes identified include TNFRSF11B, STC1, PTGS2, IL13A2, IL11, OSM, TREM1, CCR2, and CCL7 [103-107]. Expression of OSM and its receptor OSMR was recently shown to be higher in the colonic mucosa of adult patients not achieving endoscopic remission [106]. The expression of these genes predicted response to anti-TNF therapy with an area under the curve (AUC) of $73.7 \%$. However, none of these studies focused on the pediatric population. The only gene expression studies carried out in children with IBD to date $[99,108]$ measured gene expression in whole blood, instead of in inflamed tissue (Table 2).

In Salvador-Martín et al., which included 33 children, expression of SMAD7, FCGR1A, $F C G R 1 B$, and GBP1 was found to be a pharmacogenomic biomarker of early response to 
anti-TNF agents in children with IBD. SMAD7 expression was decreased in non-responders before initiation of treatment and after two weeks on the treatment [99]. The same authors conducted a transcriptome analysis which revealed 32 genes differentially expressed in children with IBD between responders and non-responders before initiation of treatment with anti-TNFs and 44 genes two weeks later. Of these, FCGR1A, FCGR1B, and GBP1 were overexpressed in non-responders after two weeks of treatment with anti-TNFs [108].

Given the invasive nature of biopsies to obtain colon samples, gene expression biomarkers from whole blood could prove advantageous, especially in children. Little is known about this subject in children with IBD. A meta-analysis found genes to be differentially expressed in the blood and colon biopsies of children with UC, thus validating the approach of identifying biomarkers of IBD in blood, although the authors did not explore efficacy of biological drugs [109]. TNF was not upregulated in damaged tissues or in whole blood. Increased expression of receptors in genes such as TNFRSF1B, OSMR, IFNAR2, and CSF2RA can explain the lack of increase in their ligand in colonic biopsies. Finally, there is a certain correspondence in gene expression between blood and colon tissue.

Ostrowski et al. identified a group of 15 genes (ANOS1, ANXA3, ATP9A, CACNA1E, COX6B2, FCGR1B, GALNT14, IL18R1, ITGB4, KLRF1, MMP9, OPLA, PFKFB3, S100A12, and $U T S 2 R$ ) in peripheral blood with the potential to discriminate between children with clinically active IBD and healthy donors, but not between adults with IBD and healthy donors [110].

Table 2. Gene expression biomarkers associated with disease activity or response to biological drugs in children with IBD.

\begin{tabular}{|c|c|c|c|c|}
\hline Gen & Comparison & Time/Tissue & Disease/Treatment & Ref \\
\hline SMAD7 & *R vs. NR & 0, $2 \mathrm{~W} /$ Blood & IBD/Anti-TNFs & [99] \\
\hline FCGR1A & ${ }^{*} \mathrm{NR}$ vs. R & $2 \mathrm{~W} /$ Blood & IBD/Anti-TNFs & [108] \\
\hline FCGR1B & *NR vs. R & $2 \mathrm{~W} /$ Blood & IBD/Anti-TNFs & [108] \\
\hline GBP1 & ${ }^{*} \mathrm{NR}$ vs. $\mathrm{R}$ & $2 \mathrm{~W} /$ Blood & IBD/Anti-TNFs & [108] \\
\hline ANOS1 & *Active IBD vs. Controls & Blood & IBD & [110] \\
\hline ANXA3 & *Active IBD vs. Controls & Blood & IBD & [110] \\
\hline ATP9A & *Active IBD vs. Controls & Blood & IBD & [110] \\
\hline CACNA1E & *Active IBD vs. Controls & Blood & IBD & [110] \\
\hline COX6B2 & *Active IBD vs. Controls & Blood & IBD & [110] \\
\hline FCGR1B & *Active IBD vs. Controls & Blood & IBD & [110] \\
\hline GALNT14 & *Active IBD vs. Controls & Blood & IBD & [110] \\
\hline IL18R1 & *Active IBD vs. Controls & Blood & IBD & [110] \\
\hline ITGB4 & *Active IBD vs. Controls & Blood & IBD & [110] \\
\hline KLRF1 & *Active IBD vs. Controls & Blood & IBD & [110] \\
\hline MMP9 & *Active IBD vs. Controls & Blood & IBD & [110] \\
\hline OPLAH & *Active IBD vs. Controls & Blood & IBD & [110] \\
\hline PFKFB3 & *Active IBD vs. Controls & Blood & IBD & [110] \\
\hline S100A12 & *Active IBD vs. Controls & Blood & IBD & [110] \\
\hline UTS2R & *Active IBD vs. Controls & Blood & IBD & [110] \\
\hline TNFRSF1B & *UC vs. Controls & Blood/CB & $\mathrm{UC}$ & [109] \\
\hline OSMR & *UC vs. Controls & Blood/CB & $\mathrm{UC}$ & [109] \\
\hline IFNAR2 & *UC vs. Controls & Blood/CB & UC & [109] \\
\hline CSFR2A & *UC vs. Controls & Blood/CB & $\mathrm{UC}$ & [109] \\
\hline
\end{tabular}

NR, non-responders; R, responders; IBD, inflammatory bowel disease; UC, ulcerative colitis; CB, colon biopsies. * Higher levels.

A role as potential biomarkers in IBD has also been proposed for micro RNAs (miRNAs) [111]. One study identified the expression of three miRNAs in whole blood associated with response to prednisone and infliximab in children with pIBD [112]. The list subsequently increased to $11 \mathrm{miRNAs}$ associated with response to anti-TNF treatment, glucocorticoids, or both [113]. The analysis of these 11 genes showed that increased baseline expression, i.e., prior to administration of anti-TNF agents, returned to levels comparable to those of healthy subjects after anti-TNF treatment in eight miRNAs (miR-126, miR-26a, miR-26b, miR-454, miR-146a, miR-146b, miR-320a, and let-7c). Furthermore, five of these 
miRNAs were also increased in biopsies of inflamed tissue (miR-146a, miR-146b, miR-320a, miR-126, and let-7c) [113]. However, the main limitation of this study was that all the recruited patients responded to treatment.

Another study with miRNAs identified miR-15a as a biomarker of activity in pediatric CD [114]. Since decreased activity directly correlates with response, this molecule could be a potential pharmacogenomic biomarker of biological drugs in children with IBD. More studies are needed to improve our knowledge of miRNAs as biomarkers of pIBD in clinical practice.

A recent search for differentially expressed genes in the anti-TNF response led the authors to suggest that IL6 levels prior to initiation of infliximab are associated with primary nonresponse (measured at 14 weeks), in addition to body mass index, disease course, and C-reactive protein levels in patients diagnosed with CD [115]. Unfortunately, these authors did not include information about the number of children recruited. It would be interesting to search for a cutoff value of IL6 as a biomarker or as a predictor of the response to biological therapy in children with IBD. Our group found that the SNP rs10499563 C (IL6) was associated with anti-TNF trough levels in adults with maintenance therapy, but not in children $[9,100]$. More studies are needed to identify the potential role of IL6 as a biomarker in children, adults, or both.

A study with 913 children with CD found a genetic signature associated with stricturing complications and that early anti-TNF therapy reduces penetrating, but not stricturing, disease complications [116]. This combination makes it possible to personalize anti-TNF treatment in children with CD.

\section{Other Biomarkers of Response to Anti-TNFs in pIBD}

Regulatory T cells (Tregs) play an essential role in the pathogenesis of IBD, in which Treg counts are decreased [117]. Anti-TNF therapy is known to increase the number and function of Tregs in IBD [118]. The study of these cells may help to predict response to anti-TNF agents, because upregulation is not as efficient in non-responders as in responders $[119,120]$.

Few studies have assessed Tregs in children, although preliminary results suggest an effect similar to that observed in adults. Ricardelli et al. showed that FOXP3+ T-cell counts were lower in the mucosal samples of children with active CD than in healthy controls. However, this difference disappeared after the initiation of infliximab [121].

Furthermore, intestinal microbiota may also modulate the immune system and play an acute role in IBD [122]. It has been suggested that defects in Treg function might induce changes in the gut microbiome, leading to loss of tolerance to commensal bacteria [123]. In children, Conte et al. observed higher numbers of mucosa-associated aerobic and facultative anaerobic bacteria in IBD patients than in healthy controls [124]. The authors also observed a decrease in counts of Bacteroides vulgatus. A subsequent study differentiating between CD and UC in children showed a decrease in counts of Faecalibacterium prausnitzii and an increase in those of Escherichia coli in children with CD [125]. However, no differences were found in the composition of microbiota in children with UC, in contrast with findings in adults [125].

Concerning anti-TNF therapy and the gut microbiome in children with IBD, a higher number of multiple short-chain, fatty-acid-producing bacteria has been associated with a sustained response to infliximab in pediatric CD [126]. In addition, infliximab increased the diversity of the gut microbiome, and its composition resembled that of healthy children. These results were recently confirmed in a larger cohort of pediatric CD patients, where bile salt hydrolase-producing bacteria are also enriched after treatment with infliximab [127].

The aforementioned data suggest that Treg count and functionality, as well as the gut microbiome, could act as relevant biomarkers of response to anti-TNFs. However, this observation is restricted to infliximab. More studies are necessary to validate these biomarkers and to find new ones associated with the different biological drugs used in pIBD. 
The list of factors thought to affect the efficacy of anti-TNFs is growing. It was recently reported that vitamin $\mathrm{D}$ deficiency was associated with a higher risk of early discontinuation of anti-TNF therapy (14.5\% vs. $0 \%)$ in children with IBD [128].

\section{Conclusions and Perspectives}

In this review, we present clinical, biochemical, genetic, genomic, and cellular biomarkers of response to anti-TNF therapy in pIBD and discuss their differences with adults. We also discuss the role of the microbiome in this disease. Some markers, such as fecal calprotectin, C-reactive protein, and serum trough anti-TNF level are supported by their utility and strong clinical evidence and are useful in current clinical practice. There are currently no predictive biomarkers, prior to treatment initiation, that can be used to guide the personalization of biologic therapy in PIBD. Genomic biomarkers need to be validated in larger cohorts of patients before they can be applied in clinical practice. Some of them are very promising and, if confirmed, could be useful in real practice in a few years.

Several reviews focusing on children with IBD also address prediction of response to anti-TNF agents. However, ours is the only one to add studies specifically performed in children diagnosed with IBD and to focus on biomarkers of response to biological drugs. Research should also be extended to other biologic drugs in IBD that are used off-label in children, such as vedolizumab and ustekinumab. Currently no clear biomarkers have been identified for these drugs in children with pIBD.

Nevertheless, regardless of the reason for the differences observed, the identification of biomarkers of response to biological drugs in pediatric IBD could help to personalize therapy and prolong the useful life of existing treatments, while we wait for new drugs to be developed. Although it is clear that the basis for personalized medicine is not yet available and remains an unmet need in daily clinical practice, the identification of response biomarkers to anti-TNF drugs could improve future treatment in pediatric patients with this chronic disease.

Author Contributions: Conceptualization, S.S.-M., A.M.-O. and L.A.L.-F.; investigation, S.S.-M., A.M.-O. and L.A.L.-F.; writing - original draft preparation, S.S.-M., A.M.-O. and L.A.L.-F.; writingreview and editing, S.S.-M., A.M.-O. and L.A.L.-F.; funding acquisition, L.A.L.-F. All authors have read and agreed to the published version of the manuscript.

Funding: This research was funded by Instituto de Salud Carlos III, grant number PI19/00792. The study was co-funded by ERDF Funds (FEDER) from the European Commission, "A way of making Europe".

Institutional Review Board Statement: Not applicable.

Informed Consent Statement: Not applicable.

Data Availability Statement: Data sharing not applicable.

Acknowledgments: We would like to thank Xandra García-Gonzalez for the critical review of the manuscript.

Conflicts of Interest: The authors declare no conflict of interest.

\section{References}

1. Kim, S.C.; Ferry, G.D. Inflammatory bowel diseases in pediatric and adolescent patients: Clinical, therapeutic, and psychosocial considerations. Gastroenterology 2004, 126, 1550-1560. [CrossRef]

2. $\quad$ Levine, A.; Griffiths, A.; Markowitz, J.; Wilson, D.C.; Turner, D.; Russell, R.K.; Fell, J.; Ruemmele, F.M.; Walters, T.; Sherlock, M.; et al. Pediatric modification of the Montreal classification for inflammatory bowel disease: The Paris classification. Inflamm. Bowel Dis. 2011, 17, 1314-1321. [CrossRef]

3. Muise, A.M.; Snapper, S.B.; Kugathasan, S. The age of gene discovery in very early onset inflammatory bowel disease. Gastroenterology 2012, 143, 285-288. [CrossRef]

4. Park, S.; Kang, Y.; Koh, H.; Kim, S. Increasing incidence of inflammatory bowel disease in children and adolescents: Significance of environmental factors. Clin. Exp. Pediatr. 2020, 63, 337-344. [CrossRef] 
5. Griffiths, A.M. Specificities of inflammatory bowel disease in childhood. Best Pract. Res. Clin. Gastroenterol. 2004, 18, 509-523. [CrossRef]

6. Henderson, P.; Wilson, D.C.; Satsangi, J. Differences in phenotype and disease course in adult and paediatric inflammatory bowel disease. Aliment. Pharmacol. Ther. 2012, 35, 391-393. [CrossRef]

7. Penagini, F.; Cococcioni, L.; Pozzi, E.; Dilillo, D.; Rendo, G.; Mantegazza, C.; Zuccotti, G.V. Biological therapy in pediatric age. Pharmacol. Res. 2020, 161, 105120. [CrossRef]

8. Lev-Tzion, R.; Turner, D. Is pediatric IBD treatment different than in adults? Minerva Gastroenterol. Dietol. 2012, 58, 137-150.

9. Salvador-Martín, S.; López-Cauce, B.; Nuñez, O.; Laserna-Mendieta, E.J.; García, M.I.; Lobato, E.; Abarca-Zabalía, J.; Sanjurjo-Saez, M.; Lucendo, A.J.; Marín-Jiménez, I.; et al. Genetic predictors of long-term response and trough levels of infliximab in crohn's disease. Pharmacol. Res. 2019, 149, 104478. [CrossRef]

10. Salvador-Martín, S.; Bossacoma, F.; Pujol-Muncunill, G.; Navas-López, V.M.; Gallego-Fernández, C.; Viada, J.; Muñoz-Codoceo, R.; Magallares, L.; Martínez-Ojinaga, E.; Moreno-Álvarez, A.; et al. Genetic Predictors of Long-term Response to Antitumor Necrosis Factor Agents in Pediatric Inflammatory Bowel Disease. J. Pediatr. Gastroenterol. Nutr. 2020, 71, 508-515. [CrossRef]

11. Cui, G.; Fan, Q.; Li, Z.; Goll, R.; Florholmen, J. Evaluation of anti-TNF therapeutic response in patients with inflammatory bowel disease: Current and novel biomarkers. EBioMedicine 2021, 66, 103329. [CrossRef] [PubMed]

12. Krawiec, P.; Pawłowska-Kamieniak, A.; Pac-Kożuchowska, E. Interleukin 10 and interleukin 10 receptor in paediatric inflammatory bowel disease: From bench to bedside lesson. J. Inflamm. 2021, 18, 1-5. [CrossRef] [PubMed]

13. Crowley, E.; Warner, N.; Pan, J.; Khalouei, S.; Elkadri, A.; Fiedler, K.; Foong, J.; Turinsky, A.L.; Bronte-Tinkew, D.; Zhang, S.; et al. Prevalence and Clinical Features of Inflammatory Bowel Diseases Associated with Monogenic Variants, Identified by Whole-Exome Sequencing in 1000 Children at a Single Center. Gastroenterology 2020, 158, 2208-2220. [CrossRef] [PubMed]

14. Corica, D.; Romano, C. Biological Therapy in Pediatric Inflammatory Bowel Disease. J. Clin. Gastroenterol. 2017, 51, 100-110. [CrossRef]

15. Grover, Z. Predicting and preventing complications in children with inflammatory bowel disease. Transl. Pediatr. 2019, 8, 70-76. [CrossRef] [PubMed]

16. Yu, Y.R.; Rodriguez, J.R. Clinical presentation of Crohn's, ulcerative colitis, and indeterminate colitis: Symptoms, extraintestinal manifestations, and disease phenotypes. Semin. Pediatr. Surg. 2017, 26, 349-355. [CrossRef]

17. Chaparro, M.; Garre, A.; Ricart, E.; Iglesias-Flores, E.; Taxonera, C.; Domènech, E.; Gisbert, J.P. Differences between childhoodand adulthood-onset inflammatory bowel disease: The CAROUSEL study from GETECCU. Aliment. Pharmacol. Ther. 2019, 49, 419-428. [CrossRef] [PubMed]

18. Rosen, M.J.; Dhawan, A.; Saeed, S.A. Inflammatory Bowel Disease in Children and Adolescents. JAMA Pediatr. 2015, 169, 1053-1060. [CrossRef]

19. Harbord, M.; Annese, V.; Vavricka, S.R.; Allez, M.; Barreiro-de Acosta, M.; Boberg, K.M.; Burisch, J.; De Vos, M.; De Vries, A.-M.; Dick, A.D.; et al. The First European Evidence-based Consensus on Extra-intestinal Manifestations in Inflammatory Bowel Disease. J. Crohn's Colitis 2016, 10, 239-254. [CrossRef]

20. Jansson, S.; Malham, M.; Paerregaard, A.; Jakobsen, C.; Wewer, V. Extraintestinal Manifestations Are Associated with Disease Severity in Pediatric Onset Inflammatory Bowel Disease. J. Pediatr. Gastroenterol. Nutr. 2020, 71, 40-45. [CrossRef]

21. Oliveira, S.B.; Monteiro, I.M. Diagnosis and management of inflammatory bowel disease in children. BMJ 2017, 357, j2083. [CrossRef]

22. Brooks, A.J.; Rowse, G.; Ryder, A.; Peach, E.J.; Corfe, B.M.; Lobo, A.J. Systematic review: Psychological morbidity in young people with inflammatory bowel disease-risk factors and impacts. Aliment. Pharmacol. Ther. 2016, 44, 3-15. [CrossRef]

23. Abraham, B.P.; Mehta, S.; El-Serag, H.B. Natural history of pediatric-onset inflammatory bowel disease: A systematic review. J. Clin. Gastroenterol. 2012, 46, 581-589. [CrossRef] [PubMed]

24. Däbritz, J.; Gerner, P.; Enninger, A.; Claßen, M.; Radke, M. Inflammatory bowel disease in childhood and adolescence-Diagnosis and treatment. Dtsch. Arztebl. Int. 2017, 114, 331-338. [CrossRef]

25. Eszter Müller, K.; Laszlo Lakatos, P.; Papp, M.; Veres, G. Incidence and Paris classification of pediatric inflammatory bowel disease. Gastroenterol. Res. Pract. 2014, 2014, 904307. [CrossRef]

26. Conrad, M.A.; Rosh, J.R. Pediatric Inflammatory Bowel Disease. Pediatr. Clin. N. Am. 2017, 64, 577-591. [CrossRef]

27. Ygberg, S.; Nilsson, A. The developing immune system-from foetus to toddler. Acta Paediatr. 2012, 101, 120-127. [CrossRef] [PubMed]

28. Filimoniuk, A.; Daniluk, U.; Samczuk, P.; Wasilewska, N.; Jakimiec, P.; Kucharska, M.; Lebensztejn, D.M.; Ciborowski, M. Metabolomic profiling in children with inflammatory bowel disease. Adv. Med. Sci. 2020, 65, 65-70. [CrossRef] [PubMed]

29. Carr, E.J.; Dooley, J.; Garcia-Perez, J.E.; Lagou, V.; Lee, J.C.; Wouters, C.; Meyts, I.; Goris, A.; Boeckxstaens, G.; Linterman, M.A.; et al. The cellular composition of the human immune system is shaped by age and cohabitation. Nat. Immunol. 2016, 17, 461-468. [CrossRef] [PubMed]

30. Aardoom, M.A.; Veereman, G.; de Ridder, L. A Review on the Use of Anti-TNF in Children and Adolescents with Inflammatory Bowel Disease. Int. J. Mol. Sci. 2019, 20, 2529. [CrossRef]

31. Ruemmele, F.; Veres, G.; Kolho, K.; Griffiths, A.; Levine, A.; Escher, J.; Dias, J.A.; Barabino, A.; Braegger, C.; Bronsky, J.; et al. Consensus guidelines of ECCO/ESPGHAN on the medical management of pediatric Crohn's disease. J. Crohn's Colitis 2014, 8, 1179-1207. [CrossRef] [PubMed] 
32. Walters, T.D.; Kim, M.-O.; Denson, L.A.; Griffiths, A.M.; Dubinsky, M.; Markowitz, J.; Baldassano, R.; Crandall, W.; Rosh, J.; Pfefferkorn, M.; et al. Increased effectiveness of early therapy with anti-tumor necrosis factor- $\alpha$ vs an immunomodulator in children with Crohn's disease. Gastroenterology 2014, 146, 383-391. [CrossRef]

33. Van Rheenen, P.F.; Aloi, M.; Assa, A.; Bronsky, J.; Escher, J.C.; Fagerberg, U.L.; Gasparetto, M.; Gerasimidis, K.; Griffiths, A.; Henderson, P.; et al. The Medical Management of Paediatric Crohn's Disease: An ECCO-ESPGHAN Guideline Update. J. Crohn's Colitis 2021, 15, 171-194. [CrossRef]

34. Feagan, B.G.; Rutgeerts, P.; Sands, B.E.; Hanauer, S.; Colombel, J.-F.; Sandborn, W.J.; Van Assche, G.; Axler, J.; Kim, H.-J.; Danese, S.; et al. Vedolizumab as induction and maintenance therapy for ulcerative colitis. N. Engl. J. Med. 2013, 369, 699-710. [CrossRef] [PubMed]

35. Feagan, B.G.; Sandborn, W.J.; Gasink, C.; Jacobstein, D.; Lang, Y.; Friedman, J.R.; Blank, M.A.; Johanns, J.; Gao, L.-L.; Miao, Y.; et al. Ustekinumab as Induction and Maintenance Therapy for Crohn's Disease. N. Engl. J. Med. 2016, 375, 1946-1960. [CrossRef]

36. Nakase, H. Optimizing the Use of Current Treatments and Emerging Therapeutic Approaches to Achieve Therapeutic Success in Patients with Inflammatory Bowel Disease. Gut Liver 2020, 14, 7-19. [CrossRef]

37. Sulz, M.C.; Burri, E.; Michetti, P.; Rogler, G.; Peyrin-Biroulet, L.; Seibold, F. Treatment Algorithms for Crohn's Disease. Digestion 2020, 101 (Suppl. S1), 43-57. [CrossRef]

38. Shim, H.H.; Chan, P.W.; Chuah, S.W.; Schwender, B.J.; Kong, S.C.; Ling, K.L. A review of vedolizumab and ustekinumab for the treatment of inflammatory bowel diseases. JGH Open Open Access J. Gastroenterol. Hepatol. 2018, 2, 223-234. [CrossRef]

39. Von Allmen, D. Pediatric Crohn's Disease. Clin. Colon Rectal Surg. 2018, 31, 80-88. [CrossRef] [PubMed]

40. Topf-Olivestone, C.; Turner, D. How effective is the use of long-term anti-TNF for paediatric IBD? Clues from real-life surveillance cohorts. Arch. Dis. Child. 2015, 100, 391-392. [CrossRef]

41. Cameron, F.L.; Wilson, M.L.; Basheer, N.; Jamison, A.; McGrogan, P.; Bisset, W.M.; Gillett, P.M.; Russell, R.K.; Wilson, D.C. Anti-TNF therapy for paediatric IBD: The Scottish national experience. Arch. Dis. Child. 2015, 100, 399-405. [CrossRef]

42. Gisbert, J.P.; Chaparro, M. Predictors of Primary Response to Biologic Treatment [Anti-TNF, Vedolizumab, and Ustekinumab] in Patients with Inflammatory Bowel Disease: From Basic Science to Clinical Practice. J. Crohn's Colitis 2020, 14, 694-709. [CrossRef]

43. Ungar, B.; Levy, I.; Yavne, Y.; Yavzori, M.; Picard, O.; Fudim, E.; Loebstein, R.; Chowers, Y.; Eliakim, R.; Kopylov, U.; et al Optimizing Anti-TNF- $\alpha$ Therapy: Serum Levels of Infliximab and Adalimumab Are Associated with Mucosal Healing in Patients with Inflammatory Bowel Diseases. Clin. Gastroenterol. Hepatol. 2016, 14, 550-557.e2. [CrossRef]

44. Ding, N.S.; Hart, A.; De Cruz, P. Systematic review: Predicting and optimising response to anti-TNF therapy in Crohn's disease-algorithm for practical management. Aliment. Pharmacol. Ther. 2016, 43, 30-51. [CrossRef]

45. Naviglio, S.; Giuffrida, P.; Stocco, G.; Lenti, M.V.; Ventura, A.; Corazza, G.R.; Di Sabatino, A. How to predict response to anti-tumour necrosis factor agents in inflammatory bowel disease. Expert Rev. Gastroenterol. Hepatol. 2018, 12, 797-810. [CrossRef]

46. Laserna-Mendieta, E.J.; Lucendo, A.J. Faecal calprotectin in inflammatory bowel diseases: A review focused on meta-analyses and routine usage limitations. Clin. Chem. Lab. Med. 2019, 57, 1295-1307. [CrossRef]

47. Scaldaferri, F.; D'Ambrosio, D.; Holleran, G.; Poscia, A.; Petito, V.; Lopetuso, L.; Graziani, C.; Laterza, L.; Pistone, M.T.; Pecere, S.; et al. Body mass index influences infliximab post-infusion levels and correlates with prospective loss of response to the drug in a cohort of inflammatory bowel disease patients under maintenance therapy with Infliximab. PLoS ONE 2017, 12, e0186575. [CrossRef] [PubMed]

48. Kennedy, N.A.; Heap, G.A.; Green, H.D.; Hamilton, B.; Bewshea, C.; Walker, G.J.; Thomas, A.; Nice, R.; Perry, M.H.; Bouri, S.; et al. Predictors of anti-TNF treatment failure in anti-TNF-naive patients with active luminal Crohn's disease: A prospective, multicentre, cohort study. Lancet Gastroenterol. Hepatol. 2019, 4, 341-353. [CrossRef]

49. Cornillie, F.; Hanauer, S.B.; Diamond, R.H.; Wang, J.; Tang, K.L.; Xu, Z.; Rutgeerts, P.; Vermeire, S. Postinduction serum infliximab trough level and decrease of $C$-reactive protein level are associated with durable sustained response to infliximab: A retrospective analysis of the ACCENT I trial. Gut 2014, 63, 1721-1727. [CrossRef] [PubMed]

50. Hendy, P.; Hart, A.; Irving, P. Anti-TNF drug and antidrug antibody level monitoring in IBD: A practical guide. Frontline Gastroenterol. 2016, 7, 122-128. [CrossRef] [PubMed]

51. Van Hoeve, K.; Dreesen, E.; Hoffman, I.; Van Assche, G.; Ferrante, M.; Gils, A.; Vermeire, S. Higher Infliximab Trough Levels Are Associated with Better Outcome in Paediatric Patients with Inflammatory Bowel Disease. J. Crohn's Colitis 2018, 12, 1316-1325. [CrossRef] [PubMed]

52. Van Hoeve, K.; Hoffman, I.; Vermeire, S. Therapeutic drug monitoring of anti-TNF therapy in children with inflammatory bowel disease. Expert Opin. Drug Saf. 2018, 17, 185-196. [CrossRef]

53. Merras-Salmio, L.; Kolho, K.-L. Clinical Use of Infliximab Trough Levels and Antibodies to Infliximab in Pediatric Patients with Inflammatory Bowel Disease. J. Pediatr. Gastroenterol. Nutr. 2017, 64, 272-278. [CrossRef]

54. Lucafò, M.; Curci, D.; Bramuzzo, M.; Alvisi, P.; Martelossi, S.; Silvestri, T.; Guastalla, V.; Labriola, F.; Stocco, G.; Decorti, G. Serum Adalimumab Levels After Induction Are Associated with Long-Term Remission in Children with Inflammatory Bowel Disease. Front. Pediatr. 2021, 9, 646671. [CrossRef]

55. Chaparro, M.; Barreiro-de Acosta, M.; Echarri, A.; Almendros, R.; Barrio, J.; Llao, J.; Gomollón, F.; Vera, M.; Cabriada, J.L.; Guardiola, J.; et al. Correlation Between Anti-TNF Serum Levels and Endoscopic Inflammation in Inflammatory Bowel Disease Patients. Dig. Dis. Sci. 2019, 64, 846-854. [CrossRef] [PubMed] 
56. Nobile, S.; Gionchetti, P.; Rizzello, F.; Calabrese, C.; Campieri, M. Mucosal healing in pediatric Crohn's disease after anti-TNF therapy: A long-term experience at a single center. Eur. J. Gastroenterol. Hepatol. 2014, 26, 458-465. [CrossRef]

57. Nuti, F.; Civitelli, F.; Bloise, S.; Oliva, S.; Aloi, M.; Latorre, G.; Viola, F.; Cucchiara, S. Prospective Evaluation of the Achievement of Mucosal Healing with Anti-TNF- $\alpha$ Therapy in a Paediatric Crohn's Disease Cohort. J. Crohn's Colitis 2016, 10, 5-12. [CrossRef] [PubMed]

58. Yarur, A.J.; Jain, A.; Sussman, D.A.; Barkin, J.S.; Quintero, M.A.; Princen, F.; Kirkland, R.; Deshpande, A.R.; Singh, S.; Abreu, M.T. The association of tissue anti-TNF drug levels with serological and endoscopic disease activity in inflammatory bowel disease: The ATLAS study. Gut 2016, 65, 249-255. [CrossRef] [PubMed]

59. Vande Casteele, N.; Ferrante, M.; Van Assche, G.; Ballet, V.; Compernolle, G.; Van Steen, K.; Simoens, S.; Rutgeerts, P.; Gils, A.; Vermeire, S. Trough Concentrations of Infliximab Guide Dosing for Patients with Inflammatory Bowel Disease. Gastroenterology 2015, 148, 1320-1329.e3. [CrossRef]

60. Mitrev, N.; Vande Casteele, N.; Seow, C.H.; Andrews, J.M.; Connor, S.J.; Moore, G.T.; Barclay, M.; Begun, J.; Bryant, R.; Chan, W.; et al. Review article: Consensus statements on therapeutic drug monitoring of anti-tumour necrosis factor therapy in inflammatory bowel diseases. Aliment. Pharmacol. Ther. 2017, 46, 1037-1053. [CrossRef] [PubMed]

61. Beltrán, B.; Iborra, M.; Sáez-González, E.; Marqués-Miñana, M.R.; Moret, I.; Cerrillo, E.; Tortosa, L.; Bastida, G.; Hinojosa, J.; Poveda-Andrés, J.L.; et al. Fecal Calprotectin Pretreatment and Induction Infliximab Levels for Prediction of Primary Nonresponse to Infliximab Therapy in Crohn's Disease. Dig. Dis. 2019, 37, 108-115. [CrossRef]

62. Yanai, H.; Lichtenstein, L.; Assa, A.; Mazor, Y.; Weiss, B.; Levine, A.; Ron, Y.; Kopylov, U.; Bujanover, Y.; Rosenbach, Y.; et al. Levels of drug and antidrug antibodies are associated with outcome of interventions after loss of response to infliximab or adalimumab. Clin. Gastroenterol. Hepatol. Off. Clin. Pract. J. Am. Gastroenterol. Assoc. 2015, 13, 522-530.e2. [CrossRef] [PubMed]

63. Courbette, O.; Aupiais, C.; Viala, J.; Hugot, J.-P.; Roblin, X.; Candon, S.; Louveau, B.; Chatenoud, L.; Martinez-Vinson, C. Trough Levels of Infliximab at W6 Are Predictive of Remission at W14 in Pediatric Crohn Disease. J. Pediatr. Gastroenterol. Nutr. 2020, 70, 310-317. [CrossRef]

64. Nanda, K.S.; Cheifetz, A.S.; Moss, A.C. Impact of antibodies to infliximab on clinical outcomes and serum infliximab levels in patients with inflammatory bowel disease (IBD): A meta-analysis. Am. J. Gastroenterol. 2013, 108, 40-47. [CrossRef] [PubMed]

65. Pallagi-Kunstár, É.; Farkas, K.; Szepes, Z.; Nagy, F.; Szúcs, M.; Kui, R.; Gyulai, R.; Bálint, A.; Wittmann, T.; Molnár, T. Utility of serum TNF- $\alpha$, infliximab trough level, and antibody titers in inflammatory bowel disease. World J. Gastroenterol. 2014, 20, 5031-5035. [CrossRef] [PubMed]

66. Cohen, R.Z.; Schoen, B.T.; Kugathasan, S.; Sauer, C.G. Management of Anti-drug Antibodies to Biologic Medications in Children with Inflammatory Bowel Disease. J. Pediatr. Gastroenterol. Nutr. 2019, 69, 551-556. [CrossRef] [PubMed]

67. Naviglio, S.; Lacorte, D.; Lucafò, M.; Cifù, A.; Favretto, D.; Cuzzoni, E.; Silvestri, T.; Pozzi Mucelli, M.; Radillo, O.; Decorti, G.; et al. Causes of Treatment Failure in Children with Inflammatory Bowel Disease Treated with Infliximab. J. Pediatr. Gastroenterol. Nutr. 2019, 68, 37-44. [CrossRef] [PubMed]

68. Ohem, J.; Hradsky, O.; Zarubova, K.; Copova, I.; Bukovska, P.; Prusa, R.; Malickova, K.; Bronsky, J. Evaluation of Infliximab Therapy in Children with Crohn's Disease Using Trough Levels Predictors. Dig. Dis. 2018, 36, 40-48. [CrossRef]

69. Rolandsdotter, H.; Marits, P.; Sundin, U.; Wikström, A.-C.; Fagerberg, U.; Finkel, Y.; Eberhardson, M. Serum-Infliximab Trough Levels in 45 Children with Inflammatory Bowel Disease on Maintenance Treatment. Int. J. Mol. Sci. 2017, 18, 575. [CrossRef]

70. Steenholdt, C.; Brynskov, J.; Thomsen, O.Ø.; Munck, L.K.; Fallingborg, J.; Christensen, L.A.; Pedersen, G.; Kjeldsen, J.; Jacobsen, B.A.; Oxholm, A.S.; et al. Individualised therapy is more cost-effective than dose intensification in patients with Crohn's disease who lose response to anti-TNF treatment: A randomised, controlled trial. Gut 2014, 63, 919-927. [CrossRef]

71. Afif, W.; Loftus, E.V.J.; Faubion, W.A.; Kane, S.V.; Bruining, D.H.; Hanson, K.A.; Sandborn, W.J. Clinical utility of measuring infliximab and human anti-chimeric antibody concentrations in patients with inflammatory bowel disease. Am. J. Gastroenterol. 2010, 105, 1133-1139. [CrossRef] [PubMed]

72. Overkleeft, R.; Tommel, J.; Evers, A.W.M.; den Dunnen, J.T.; Roos, M.; Hoefmans, M.-J.; Schrader, W.E.; Swen, J.J.; Numans, M.E.; Houwink, E.J.F. Using Personal Genomic Data within Primary Care: A Bioinformatics Approach to Pharmacogenomics. Genes 2020, 11, 1443. [CrossRef] [PubMed]

73. Choi, S.Y.; Kang, B.; Lee, J.H.; Choe, Y.H. Clinical Use of Measuring Trough Levels and Antibodies against Infliximab in Patients with Pediatric Inflammatory Bowel Disease. Gut Liver 2017, 11, 55-61. [CrossRef]

74. Carman, N.; Mack, D.R.; Benchimol, E.I. Therapeutic Drug Monitoring in Pediatric Inflammatory Bowel Disease. Curr. Gastroenterol. Rep. 2018, 20, 18. [CrossRef] [PubMed]

75. Pinto Pais, I.; Espinheira, M.C.; Trindade, E.; Amil Dias, J. Optimizing Antitumor Necrosis Factor Treatment in Pediatric Inflammatory Bowel Disease with Therapeutic Drug Monitoring. J. Pediatr. Gastroenterol. Nutr. 2020, 71, 12-18. [CrossRef]

76. Deora, V.; Kozak, J.; El-Kalla, M.; Huynh, H.Q.; El-Matary, W. Therapeutic drug monitoring was helpful in guiding the decisionmaking process for children receiving infliximab for inflammatory bowel disease. Acta Paediatr. 2017, 106, 1863-1867. [CrossRef] [PubMed]

77. Jongsma, M.M.E.; Winter, D.A.; Huynh, H.Q.; Norsa, L.; Hussey, S.; Kolho, K.-L.; Bronsky, J.; Assa, A.; Cohen, S.; Lev-Tzion, R.; et al. Infliximab in young paediatric IBD patients: It is all about the dosing. Eur. J. Pediatr. 2020, 179, 1935-1944. [CrossRef] 
78. Papamichael, K.; Cheifetz, A.S.; Melmed, G.Y.; Irving, P.M.; Vande Casteele, N.; Kozuch, P.L.; Raffals, L.E.; Baidoo, L.; Bressler, B.; Devlin, S.M.; et al. Appropriate Therapeutic Drug Monitoring of Biologic Agents for Patients with Inflammatory Bowel Diseases. Clin. Gastroenterol. Hepatol. Off. Clin. Pract. J. Am. Gastroenterol. Assoc. 2019, 17, 1655-1668.e3. [CrossRef]

79. Papamichael, K.; Vajravelu, R.K.; Vaughn, B.P.; Osterman, M.T.; Cheifetz, A.S. Proactive Infliximab Monitoring Following Reactive Testing is Associated with Better Clinical Outcomes Than Reactive Testing Alone in Patients with Inflammatory Bowel Disease. J. Crohn's Colitis 2018, 12, 804-810. [CrossRef] [PubMed]

80. Kelly, O.B.; Donnell, S.O.; Stempak, J.M.; Steinhart, A.H.; Silverberg, M.S. Therapeutic Drug Monitoring to Guide Infliximab Dose Adjustment is Associated with Better Endoscopic Outcomes than Clinical Decision Making Alone in Active Inflammatory Bowel Disease. Inflamm. Bowel Dis. 2017, 23, 1202-1209. [CrossRef]

81. Fernandes, S.R.; Bernardo, S.; Simões, C.; Gonçalves, A.R.; Valente, A.; Baldaia, C.; Moura Santos, P.; Correia, L.A.; Tato Marinho, R. Proactive Infliximab Drug Monitoring Is Superior to Conventional Management in Inflammatory Bowel Disease. Inflamm. Bowel Dis. 2020, 26, 263-270. [CrossRef] [PubMed]

82. Lyles, J.L.; Mulgund, A.A.; Bauman, L.E.; Su, W.; Fei, L.; Chona, D.L.; Sharma, P.; Etter, R.K.; Hellmann, J.; Denson, L.A.; et al. Effect of a Practice-wide Anti-TNF Proactive Therapeutic Drug Monitoring Program on Outcomes in Pediatric Patients with Inflammatory Bowel Disease. Inflamm. Bowel Dis. 2021, 27, 482-492. [CrossRef] [PubMed]

83. Assa, A.; Matar, M.; Turner, D.; Broide, E.; Weiss, B.; Ledder, O.; Guz-Mark, A.; Rinawi, F.; Cohen, S.; Topf-Olivestone, C.; et al. Proactive Monitoring of Adalimumab Trough Concentration Associated with Increased Clinical Remission in Children with Crohn's Disease Compared with Reactive Monitoring. Gastroenterology 2019, 157, 985-996.e2. [CrossRef] [PubMed]

84. Van Hoeve, K.; Dreesen, E.; Hoffman, I.; Van Assche, G.; Ferrante, M.; Gils, A.; Vermeire, S. Adequate Infliximab Exposure During Induction Predicts Remission in Paediatric Patients with Inflammatory Bowel Disease. J. Pediatr. Gastroenterol. Nutr. 2019, 68, 847-853. [CrossRef]

85. Ostrowski, J.; Paziewska, A.; Lazowska, I.; Ambrozkiewicz, F.; Goryca, K.; Kulecka, M.; Rawa, T.; Karczmarski, J.; Dabrowska, M.; Zeber-Lubecka, N.; et al. Genetic architecture differences between pediatric and adult-onset inflammatory bowel diseases in the Polish population. Sci. Rep. 2016, 6, 39831. [CrossRef]

86. Katsanos, K.H.; Papadakis, K.A. Pharmacogenetics of inflammatory bowel disease. Pharmacogenomics 2014, 15, $2049-2062$. [CrossRef] [PubMed]

87. Bank, P.C.; Swen, J.J.; Guchelaar, H.-J. Pharmacogenetic biomarkers for predicting drug response. Expert Rev. Mol. Diagn. 2014, 14, 723-735. [CrossRef] [PubMed]

88. López-Hernández, R.; Valdés, M.; Campillo, J.A.; Martínez-García, P.; Salama, H.; Bolarin, J.M.; Martínez, H.; Moya-Quiles, M.R.; Minguela, A.; Sánchez-Torres, A.; et al. Pro-and anti-inflammatory cytokine gene single-nucleotide polymorphisms in inflammatory bowel disease. Int. J. Immunogenet. 2015, 42, 38-45. [CrossRef]

89. Bek, S.; Nielsen, J.V.; Bojesen, A.B.; Franke, A.; Bank, S.; Vogel, U.; Andersen, V. Systematic review: Genetic biomarkers associated with anti-TNF treatment response in inflammatory bowel diseases. Aliment. Pharmacol. Ther. 2016, 44, 554-567. [CrossRef]

90. Prieto-Perez, R.; Almoguera, B.; Cabaleiro, T.; Hakonarson, H.; Abad-Santos, F. Association between Genetic Polymorphisms and Response to Anti-TNFs in Patients with Inflammatory Bowel Disease. Int. J. Mol. Sci. 2016, 17, 225. [CrossRef] [PubMed]

91. Rufini, S.; Ciccacci, C.; Novelli, G.; Borgiani, P. Pharmacogenetics of inflammatory bowel disease: A focus on Crohn's disease. Pharmacogenomics 2017, 18, 1095-1114. [CrossRef] [PubMed]

92. Bank, S.; Julsgaard, M.; Abed, O.K.; Burisch, J.; Broder Brodersen, J.; Pedersen, N.K.; Gouliaev, A.; Ajan, R.; Nytoft Rasmussen, D.; Honore Grauslund, C.; et al. Polymorphisms in the NFkB, TNF-alpha, IL-1beta, and IL-18 pathways are associated with response to anti-TNF therapy in Danish patients with inflammatory bowel disease. Aliment. Pharmacol. Ther. 2019, 49, 890-903. [CrossRef] [PubMed]

93. Yamamoto-Furusho, J.K. Pharmacogenetics in inflammatory bowel disease: Understanding treatment response and personalizing therapeutic strategies. Pharmgenom. Pers. Med. 2017, 10, 197-204. [CrossRef] [PubMed]

94. Lacruz-Guzmán, D.; Torres-Moreno, D.; Pedrero, F.; Romero-Cara, P.; García-Tercero, I.; Trujillo-Santos, J.; Conesa-Zamora, P. Influence of polymorphisms and TNF and IL1 $\beta$ serum concentration on the infliximab response in Crohn's disease and ulcerative colitis. Eur. J. Clin. Pharmacol. 2013, 69, 431-438. [CrossRef] [PubMed]

95. Dezelak, M.; Repnik, K.; Koder, S.; Ferkolj, I.; Potocnik, U. A Prospective Pharmacogenomic Study of Crohn's Disease Patients during Routine Therapy with Anti-TNF-alpha Drug Adalimumab: Contribution of ATG5, NFKB1, and CRP Genes to Pharmacodynamic Variability. OMICS 2016, 20, 296-309. [CrossRef]

96. Bank, S.; Andersen, P.S.; Burisch, J.; Pedersen, N.; Roug, S.; Galsgaard, J.; Turino, S.Y.; Brodersen, J.B.; Rashid, S.; Rasmussen, B.K.; et al. Associations between functional polymorphisms in the NFkappaB signaling pathway and response to anti-TNF treatment in Danish patients with inflammatory bowel disease. Pharmacogenom. J. 2014, 14, 526-534. [CrossRef]

97. Sazonovs, A.; Kennedy, N.A.; Moutsianas, L.; Heap, G.A.; Rice, D.L.; Reppell, M.; Bewshea, C.M.; Chanchlani, N.; Walker, G.J.; Perry, M.H.; et al. HLA-DQA1*05 Carriage Associated with Development of Anti-Drug Antibodies to Infliximab and Adalimumab in Patients with Crohn's Disease. Gastroenterology 2020, 158, 189-199. [CrossRef]

98. Dubinsky, M.C.; Mei, L.; Friedman, M.; Dhere, T.; Haritunians, T.; Hakonarson, H.; Kim, C.; Glessner, J.; Targan, S.R.; McGovern, D.P.; et al. Genome wide association (GWA) predictors of anti-TNFalpha therapeutic responsiveness in pediatric inflammatory bowel disease. Inflamm. Bowel Dis. 2010, 16, 1357-1366. [CrossRef] [PubMed] 
99. Salvador-Martín, S.; Raposo-Gutiérrez, I.; Navas-López, V.M.; Gallego-Fernández, C.; Moreno-álvarez, A.; Solar-Boga, A.; Muñoz-Codoceo, R.; Magallares, L.; Martínez-Ojinaga, E.; Fobelo, M.J.; et al. Gene signatures of early response to anti-TNF drugs in pediatric inflammatory bowel disease. Int. J. Mol. Sci. 2020, 21, 3364. [CrossRef]

100. Salvador-Martín, S.; Pujol-Muncunill, G.; Bossacoma, F.; Navas-López, V.M.; Gallego-Fernández, C.; Segarra, O.; Clemente, S.; Muñoz-Codoceo, R.; Viada, J.; Magallares, L.; et al. Pharmacogenetics of trough serum anti-TNF levels in paediatric inflammatory bowel disease. Br. J. Clin. Pharmacol. 2021, 87, 447-457. [CrossRef] [PubMed]

101. Curci, D.; Lucafò, M.; Cifù, A.; Fabris, M.; Bramuzzo, M.; Martelossi, S.; Franca, R.; Decorti, G.; Stocco, G. Pharmacogenetic variants of infliximab response in young patients with inflammatory bowel disease. Clin. Transl. Sci. 2021, 1-9. [CrossRef]

102. Kugathasan, S.; Baldassano, R.N.; Bradfield, J.P.; Sleiman, P.M.A.; Imielinski, M.; Guthery, S.L.; Cucchiara, S.; Kim, C.E.; Frackelton, E.C.; Annaiah, K.; et al. Loci on 20q13 and 21q22 are associated with pediatric-onset inflammatory bowel disease. Nat. Genet. 2008, 40, 1211-1215. [CrossRef]

103. Arijs, I.; Li, K.; Toedter, G.; Quintens, R.; Van Lommel, L.; Van Steen, K.; Leemans, P.; De Hertogh, G.; Lemaire, K.; Ferrante, M.; et al. Mucosal gene signatures to predict response to infliximab in patients with ulcerative colitis. Gut 2009, 58, 1612-1619. [CrossRef]

104. Arijs, I.; Quintens, R.; Van Lommel, L.; Van Steen, K.; De Hertogh, G.; Lemaire, K.; Schraenen, A.; Perrier, C.; Van Assche, G.; Vermeire, S.; et al. Predictive value of epithelial gene expression profiles for response to infliximab in Crohn's disease. Inflamm. Bowel Dis. 2010, 16, 2090-2098. [CrossRef] [PubMed]

105. Toedter, G.; Li, K.; Marano, C.; Ma, K.; Sague, S.; Huang, C.C.; Song, X.-Y.; Rutgeerts, P.; Baribaud, F. Gene Expression Profiling and Response Signatures Associated with Differential Responses to Infliximab Treatment in Ulcerative Colitis. Am. J. Gastroenterol. 2011, 106, 1272-1280. [CrossRef]

106. Verstockt, S.; Verstockt, B.; Machiels, K.; Vancamelbeke, M.; Ferrante, M.; Cleynen, I.; De Hertogh, G.; Vermeire, S. Oncostatin M Is a Biomarker of Diagnosis, Worse Disease Prognosis, and Therapeutic Nonresponse in Inflammatory Bowel Disease. Inflamm. Bowel Dis. 2021, 27, 1564-1575. [CrossRef] [PubMed]

107. Gaujoux, R.; Starosvetsky, E.; Maimon, N.; Vallania, F.; Bar-Yoseph, H.; Pressman, S.; Weisshof, R.; Goren, I.; Rabinowitz, K.; Waterman, M.; et al. Cell-centred meta-Analysis reveals baseline predictors of anti-TNF $\alpha$ non-response in biopsy and blood of patients with IBD. Gut 2019, 68, 604-614. [CrossRef] [PubMed]

108. Salvador-Martín, S.; Kaczmarczyk, B.; Álvarez, R.; Navas-López, V.M.; Gallego-Fernández, C.; Moreno-Álvarez, A.; Solar-Boga, A.; Sánchez, C.; Tolin, M.; Velasco, M.; et al. Whole Transcription Profile of Responders to Anti-TNF Drugs in Pediatric Inflammatory Bowel Disease. Pharmaceutics 2021, 13, 77. [CrossRef]

109. Li, X.; Lee, E.J.; Gawel, D.R.; Lilja, S.; Schäfer, S.; Zhang, H.; Benson, M. Meta-Analysis of Expression Profiling Data Indicates Need for Combinatorial Biomarkers in Pediatric Ulcerative Colitis. J. Immunol. Res. 2020, 2020, 8279619. [CrossRef] [PubMed]

110. Ostrowski, J.; Dabrowska, M.; Lazowska, I.; Paziewska, A.; Balabas, A.; Kluska, A.; Kulecka, M.; Karczmarski, J.; Ambrozkiewicz, F.; Piatkowska, M.; et al. Redefining the Practical Utility of Blood Transcriptome Biomarkers in Inflammatory Bowel Diseases. J. Crohn's Colitis 2019, 13, 626-633. [CrossRef]

111. Soroosh, A.; Koutsioumpa, M.; Pothoulakis, C.; Iliopoulos, D. Functional role and therapeutic targeting of microRNAs in inflammatory bowel disease. Am. J. Physiol. Gastrointest. Liver Physiol. 2018, 314, G256-G262. [CrossRef] [PubMed]

112. Heier, C.R.; Fiorillo, A.A.; Chaisson, E.; Gordish-Dressman, H.; Hathout, Y.; Damsker, J.M.; Hoffman, E.P.; Conklin, L.S Identification of Pathway-Specific Serum Biomarkers of Response to Glucocorticoid and Infliximab Treatment in Children with Inflammatory Bowel Disease. Clin. Transl. Gastroenterol. 2016, 7, e192. [CrossRef]

113. Batra, S.K.; Heier, C.R.; Diaz-Calderon, L.; Tully, C.B.; Fiorillo, A.A.; van den Anker, J.; Conklin, L.S. Serum miRNAs Are Pharmacodynamic Biomarkers Associated with Therapeutic Response in Pediatric Inflammatory Bowel Disease. Inflamm. Bowel Dis. 2020, 26, 1597-1606. [CrossRef] [PubMed]

114. Tang, W.-J.; Peng, K.-Y.; Tang, Z.-F.; Wang, Y.-H.; Xue, A.-J.; Huang, Y. MicroRNA-15a-cell division cycle 42 signaling pathway in pathogenesis of pediatric inflammatory bowel disease. World J. Gastroenterol. 2018, 24, 5234-5245. [CrossRef]

115. Chen, Y.; Li, H.; Feng, Q.; Shen, J. Development and Validation of an Interleukin-6 Nomogram to Predict Primary Non-Response to Infliximab in Crohn's Disease Patients: From Bedside to Bioinformatics. SSRN Electron. J. 2020, 12, 1-9. [CrossRef]

116. Kugathasan, S.; Denson, L.A.; Walters, T.D.; Kim, M.-O.; Marigorta, U.M.; Schirmer, M.; Mondal, K.; Liu, C.; Griffiths, A.; Noe, J.D.; et al. Prediction of complicated disease course for children newly diagnosed with Crohn's disease: A multicentre inception cohort study. Lancet 2017, 389, 1710-1718. [CrossRef]

117. Maul, J.; Loddenkemper, C.; Mundt, P.; Berg, E.; Giese, T.; Stallmach, A.; Zeitz, M.; Duchmann, R. Peripheral and intestinal regulatory CD4+ CD25(high) T cells in inflammatory bowel disease. Gastroenterology 2005, 128, 1868-1878. [CrossRef]

118. Boschetti, G.; Nancey, S.; Sardi, F.; Roblin, X.; Flourié, B.; Kaiserlian, D. Therapy with anti-TNF $\alpha$ antibody enhances number and function of Foxp3 (+) regulatory T cells in inflammatory bowel diseases. Inflamm. Bowel Dis. 2011, 17, 160-170. [CrossRef]

119. Li, Z.; Vermeire, S.; Bullens, D.; Ferrante, M.; Van Steen, K.; Noman, M.; Rutgeerts, P.; Ceuppens, J.L.; Van Assche, G. Restoration of Foxp3+ Regulatory T-cell Subsets and Foxp3- Type 1 Regulatory-like T Cells in Inflammatory Bowel Diseases During Anti-Tumor Necrosis Factor Therapy. Inflamm. Bowel Dis. 2015, 21, 2418-2428. [CrossRef]

120. Li, Z.; Arijs, I.; De Hertogh, G.; Vermeire, S.; Noman, M.; Bullens, D.; Coorevits, L.; Sagaert, X.; Schuit, F.; Rutgeerts, P.; et al Reciprocal changes of Foxp3 expression in blood and intestinal mucosa in IBD patients responding to infliximab. Inflamm. Bowel Dis. 2010, 16, 1299-1310. [CrossRef] [PubMed] 
121. Ricciardelli, I.; Lindley, K.J.; Londei, M.; Quaratino, S. Anti tumour necrosis-alpha therapy increases the number of FOXP3 regulatory T cells in children affected by Crohn's disease. Immunology 2008, 125, 178-183. [CrossRef]

122. Marteau, P.; Lepage, P.; Mangin, I.; Suau, A.; Doré, J.; Pochart, P.; Seksik, P. Review article: Gut flora and inflammatory bowel disease. Aliment. Pharmacol. Ther. 2004, 20 (Suppl. S4), 18-23. [CrossRef]

123. Macpherson, A.; Khoo, U.Y.; Forgacs, I.; Philpott-Howard, J.; Bjarnason, I. Mucosal antibodies in inflammatory bowel disease are directed against intestinal bacteria. Gut 1996, 38, 365-375. [CrossRef]

124. Conte, M.P.; Schippa, S.; Zamboni, I.; Penta, M.; Chiarini, F.; Seganti, L.; Osborn, J.; Falconieri, P.; Borrelli, O.; Cucchiara, S. Gut-associated bacterial microbiota in paediatric patients with inflammatory bowel disease. Gut 2006, 55, 1760-1767. [CrossRef]

125. Schwiertz, A.; Jacobi, M.; Frick, J.-S.; Richter, M.; Rusch, K.; Köhler, H. Microbiota in pediatric inflammatory bowel disease. J. Pediatr. 2010, 157, 240-244.e1. [CrossRef] [PubMed]

126. Wang, Y.; Gao, X.; Ghozlane, A.; Hu, H.; Li, X.; Xiao, Y.; Li, D.; Yu, G.; Zhang, T. Characteristics of Faecal Microbiota in Paediatric Crohn's Disease and Their Dynamic Changes During Infliximab Therapy. J. Crohn's Colitis 2018, 12, 337-346. [CrossRef]

127. Wang, Y.; Gao, X.; Zhang, X.; Xiao, F.; Hu, H.; Li, X.; Dong, F.; Sun, M.; Xiao, Y.; Ge, T.; et al. Microbial and metabolic features associated with outcome of infliximab therapy in pediatric Crohn's disease. Gut Microbes 2021, 13, 1-18. [CrossRef] [PubMed]

128. Hizarcioglu-Gulsen, H.; Kaplan, J.L.; Moran, C.J.; Israel, E.J.; Lee, H.; Winter, H. The Impact of Vitamin D on Response to Anti-tumor Necrosis Factor- $\alpha$ Therapy in Children with Inflammatory Bowel Disease. J. Pediatr. Gastroenterol. Nutr. 2021, 72, e125-e131. [CrossRef] [PubMed] 